\title{
Stability Test of PACAP in Eye Drops
}

\author{
Anita K. Kovacs ${ }^{1}$ (D) Tamas Atlasz $^{2,3}$ (D) $\cdot$ Dora Werling $^{2,4}$ (D) $\cdot$ Edina Szabo $^{2}$ (D) $\cdot$ Dora Reglodi $^{2}$ (D) $\cdot$ Gabor K. Toth $^{1}$ (D)
}

Received: 8 January 2020 / Accepted: 12 March 2020 / Published online: 22 April 2020

(C) The Author(s) 2020

\begin{abstract}
PACAP is a neuropeptide with widespread distribution and diverse biological functions. It has strong cytoprotective effects mediated mainly through specific PAC1 receptors. Experimental data show protective effects of PACAP in the retina and cornea in several pathological conditions. Although intravitreal injections are a common practice in some ocular diseases, delivery of therapeutic agents in the form of eye drops would be more convenient and would lead to fewer side effects. We have previously shown that PACAP, in the form of eye drops, is able to pass through the ocular barriers and can exert retinoprotective effects. As eye drops represent a promising form of administration of PACAP in ocular diseases, it is important to investigate the stability of PACAP in solutions used in eye drops. In this study, the stability of PACAP1-27 and PACAP1-38 in eye drops was measured in four common media and a commercially available artificial tear solution at both room temperature and $+4{ }^{\circ} \mathrm{C}$. Mass spectrometry results show that the highest stability was gained with PACAP1-38 in water and $0.9 \%$ saline solution at $+4{ }^{\circ} \mathrm{C}$, representing 80 90\% drug persistence after 2 weeks. PACAP1-38 in the artificial tear showed very fast degradation at room temperature, but was stable at $+4{ }^{\circ} \mathrm{C}$. In summary, PACAP1-38 has higher stability than PACAP1-27, with highest stability at $+4{ }^{\circ} \mathrm{C}$ in water solution, but both peptides in each medium can be stored for relatively longer periods without significant degradation. These data can provide reference for future therapeutic use of PACAP in eye drops.
\end{abstract}

Keywords PACAP $\cdot$ Eye drops $\cdot$ Stability $\cdot$ Degradation

\section{Introduction}

The neuropeptide pituitary adenylate cyclase activating polypeptide (PACAP) exists in two active forms, PACAP1-38 and PACAP1-27, both of which are well-established neuro- and general cytoprotective peptides, with 38 and 27 amino acid residues, respectively (Reglodi et al. 2017, 2018a, b; Shioda and Nakamachi 2015). PACAP1-27 is the form with the shorter C-terminal, representing about $10 \%$ of the naturally occurring peptide (Miyata et al. 1990; Vaudry et al. 2009).

Tamas Atlasz

attam@gamma.ttk.pte.hu

1 Department of Medical Chemistry, Faculty of Medicine, University of Szeged, Dom Sq 8, Szeged H-6720, Hungary

2 Department of Anatomy, MTA-PTE PACAP Research Group, Medical School, University of Pecs, Szigeti str 12, Pecs H-7624, Hungary

3 Department of Sportbiology, University of Pecs, Ifjusag str 6, Pecs H-7624, Hungary

4 Department of Ophthalmology, Medical School, University of Pecs, Rakoczi str 2, Pecs H-7623, Hungary
Both PACAP forms occur in most organs, with the highest expression levels in the nervous system, endocrine glands and testis, but several peripheral organs also have measurable levels of PACAP (Fulop et al. 2019; Horvath et al. 2019; Reglodi et al. 2018c; Vaudry et al. 2009). PACAP and its receptors are also found in ocular tissues, including the lacrimal gland, conjunctiva, inner eye muscles and different layers of the eye. It has been found in all three layers of the eyecup: the fibrous, vascular and nervous layers (Atlasz et al. 2016; Seki et al. 2000a, b). PACAP exerts several different effects in the eye. It affects tear secretion (Nakamachi et al. 2016), influences muscle responses of the iris (Yamaji et al. 2005), increases blood flow in the eye (Dorner et al. 1998) and regulates pigment epithelial cell functions (Fabian et al. 2012, 2019; Maugeri et al. 2019a). Most importantly, as a general protective peptide found not only in the central nervous system but several peripheral organs as well (Laszlo et al. 2019; Liu et al. 2019; Polanco and Pennuto 2018; Reglodi et al. 2018d, e; Shioda et al. 2019; Szegeczki et al. 2019), PACAP has been shown to exert diverse retinoprotective effects in models of toxic, ischemic, inflammatory and traumatic retinal injuries (Atlasz et al. 2016, 2019; Cheng et al. 2018; Endo et al. 2011; Gabriel et al. 2019; Kvarik et al. 2016; Seki et al. 2008; Szabadfi et al. 2016; Vaczy et al. 2016; Ye et al. 
2019a, b). Several retinal cell types can be protected by PACAP, including ganglion cells, bipolar neurons, amacrine and pigment epithelial cells (Atlasz et al. 2008; Fabian et al. 2019; Maugeri et al. 2019a; Szabadfi et al. 2012).

PACAP has protective effects not only in the retina, but also in the cornea, where PACAP and its receptors are present in the cornea (Maugeri et al. 2018, 2019b, c; Wang et al. 1995). A few studies have investigated the local effects of PACAP on the cornea. A study in rabbits found that PACAP1-27 eye drops promoted the growth of neuronal processes in the cornea and accelerated recovery of corneal sensitivity (Fukiage et al. 2007). Although it focused only on neuronal recovery, the study drew attention to the possibility that PACAP, in the form of eye drops, could enhance corneal recovery. Indeed, the enhancement of corneal regeneration by topical administration of PACAP was subsequently confirmed in two independent studies (Ma et al. 2015; Nakamachi et al. 2016). PACAP has also demonstrated protective effects on corneal endothelial cells, indicating an important trophic function of the peptide in the cornea (Maugeri et al. 2018, 2019b, c). In in vivo studies, PACAP was given in the form of eye drops in order to exert local effects on the cornea. In contrast, most studies showing retinoprotective effects of the peptide have utilized intravitreal administration. Intravitreal injections, despite their wide clinical use, have the distinct disadvantage of being invasive (Atlasz et al. 2016; Shioda and Nakamachi 2015). Recently, in a model of ischemic retinopathy, we provided evidence that both PACAP forms, given as eye drops, are able to pass through the ocular barriers and reach the retina, where they can exert retinoprotective effects (Werling et al. 2016, 2017). This shows that PACAP treatment as eye drops is a promising therapeutic approach not only in corneal diseases, but also in retinal pathologies. Therefore, it is important to investigate the stability of PACAP in different solutions used in ophthalmic practice. Since the ocular application of PACAP is a potential therapeutic approach in several diseases, including dry eye syndrome (Shioda et al. 2019), the aim of the present study was to analyze the stability of PACAP1-27 and PACAP1-38 in the most commonly used eye drop solvents.

\section{Materials and Methods}

\section{Materials}

PACAP1-27 and PACAP1-38 were synthesized in our laboratory on a CEM Liberty microwave peptide synthesizer (Matthews, NC, USA) and were dissolved in the following sterile vehicles: (i) $0.9 \%$ saline solution, (ii) benzalkonium chloride solution for ophthalmic use (SOCB), (iii) thimerosal solution for ophthalmic use and (iv) water for injection, obtained from the Faculty Central Pharmacy, Faculty of
Medicine, University of Szeged. A commercially available artificial tear solution (Systane Ultra ${ }^{\circledR}$, Alcon, Switzerland) was also used in the experiment.

Analytical reversed-phase high-performance liquid chromatography (RP-HPLC) was performed on an Agilent 1200 Series separation system with diode array and multiple wavelength detector (Waldbronn, Germany), with a Luna C18(2) $100 \AA$ column $(10 \mu \mathrm{m}, 250 \times 4.6 \mathrm{~mm}$; Phenomenex, Torrance, CA, USA). The chromatography was carried out at room temperature (RT), with a flow rate maintained at $1.2 \mathrm{~mL} \mathrm{~min}^{-1}$ at a wavelength of $220 \mathrm{~nm}$ [mobile phase solvent A: $0.1 \%$ TFA in Milli-Q water; solvent B: $0.1 \%$ TFA in acetonitrile $(\mathrm{AcN})$ ] using gradient elution. Mass spectrometry (MS) data were collected on a Waters SQ Detector (Milford, MA, USA) with an API mass spectrometer in positive ion mode.

\section{Peptide Synthesis and Purification}

For the experiment, the synthesized peptides at the University of Szeged (Szeged, Hungary) were as follows: PACAP1-27: H-His-Ser-Asp-Gly-Ile-Phe-Thr-Asp-Ser-Tyr-Ser-Arg-TyrArg-Lys-Gln-Met-Ala-Val-Lys-Lys-Tyr-Leu-Ala-Ala-ValLeu-NH ${ }_{2}$; PACAP1-38: H-His-Ser-Asp-Gly-Ile-Phe-ThrAsp-Ser-Tyr-Ser-Arg-Tyr-Arg-Lys-Gln-Met-Ala-Val-LysLys-Tyr-Leu-Ala-Ala-Val-Leu-Gly-Lys-Arg-Tyr-Lys-GlnArg-Val-Lys-Asn-Lys- $\mathrm{NH}_{2}$. The sequences were synthesized by a solid-phase technique utilizing Fmoc (fluorenylmethyloxycarbonyl) chemistry. The peptide chains were elongated on a Rink amide MBHA resin $(1.1 \mathrm{mmol} / \mathrm{g})$, and the syntheses were carried out using a CEM Liberty microwave peptide synthesizer. The side-chain protecting groups were as follows: Fmoc-His(Trt) (Trt: trityl), Fmoc-Ser(tBu) (tBu: tert-butyl), Fmoc-Asp(tBu), Fmoc-Thr(tBu), FmocTyr(tBu), Fmoc-Arg(Pbf) (Pbf: 2, 2, 4,6, 7 pentamethyldihydrobenzofuran-5-sulfonyl), Fmoc-Lys(Boc) (Boc: tert-butyloxycarbonyl). Coupling was performed with HBTU. The completed peptide resins were treated with TFA/ water/TIS $(93: 5: 2, v / \mathrm{v})$ at RT for $2.5 \mathrm{~h}$. The reagents were removed, and the resulting free peptides were solubilized in $10 \%$ aqueous acetic acid, filtered and lyophilized. Next, 120 $150 \mathrm{mg}$ of crude peptides was dissolved in $1.5 \mathrm{~mL} 5 \% \mathrm{~m} / \mathrm{m}$ acetic acid, and then filtered using a $0.45 \mu \mathrm{m}$ nylon filter. Gradient elution was used, $20-40 \%$ eluent B for $50 \mathrm{~min}$ at a flow rate of $3 \mathrm{~mL} \min ^{-1}$, with detection at $220 \mathrm{~nm}$. Pure fractions were collected and lyophilized to give a white material, with weight of 55-63 mg.

\section{Stability Testing}

The stability of the peptides was examined with LC-MS in four media commonly used in ophthalmology: (i) $0.9 \%$ saline solution, (ii) benzalkonium chloride solution for ophthalmic 
use (SOCB), (iii) thimerosal solution for ophthalmic use and (iv) water for injection. First, $0.5 \mathrm{mg}$ peptide was dissolved in $0.5 \mathrm{~mL}$ solvent; after dissolution, the resulting liquids were halved. One half of the solvent was cooled to and maintained at $+4{ }^{\circ} \mathrm{C}$; the other half was kept at RT. After 3, 6, 8, 11 and 14 days, $40 \mu \mathrm{L}$ of the given solutions was examined. The stability of PACAP1-38, which showed higher stability in every condition, was also tested in a commercially available artificial tear solution as medium [ingredients: polyethylene glycol 400, propylene glycol, hydroxypropyl guar, sorbitol, aminomethyl propanol, potassium chloride, sodium chloride, $0.001 \%$ Polyquad $^{\circledR}$ (polidronium chloride)], following the same protocol.

\section{Results}

Table 1 and Figs. 1 and 2 show the stability results for PACAP1-27 in the four media at the two experimental temperatures (RT and $+4{ }^{\circ} \mathrm{C}$ ) over a 2 -week period. The results show that at $+4{ }^{\circ} \mathrm{C}$, all four solutions have significantly higher stability than the solutions at RT, and the rate of degradation is higher in the SOCB and thimerosal solution than in the other two vehicles $(0.9 \%$ saline and water). While more than $90 \%$ of PACAP1-27 was still intact at $+4{ }^{\circ} \mathrm{C}$ after 14 days, only $25 \%$ remained un-degraded at RT. In contrast, PACAP1-27 was almost completely degraded in benzalkonium chloride solution at RT, while $65 \%$ remained intact at the colder temperature.

PACAP1-38 solutions proved to be more stable than PACAP1-27 in the same four media under the same thermal conditions (Table 2, Figs. 3 and 4 ). At $+4{ }^{\circ} \mathrm{C}$, all four solutions retained more than $90 \%$ of PACAP1-38 un-degraded, and even after 2 weeks, more than $90 \%$ of the original peptide was measured in saline and water solutions, and more than $75 \%$ in the other two solutions.

PACAP1-38 stability was also measured in a commercially available artificial tear solution (Systane ${ }^{\circledR}$ Ultra) at the two experimental temperatures over a 2 -week period (Table 3 and Fig. 5). The results showed that the lower temperature gave higher stability, similar to the other examined solutions, but values were worse than in the other solvents during the second week.

LC-MS measurements showed that a lower temperature $\left(+4{ }^{\circ} \mathrm{C}\right)$ resulted in higher stability for both peptides in all media, but PACAP1-38 had higher stability than PACAP127 in all media at both experimental temperatures. Both PACAP1-27 and PACAP1-38 solutions with 0.9\% saline solution and water for injection were more stable at both temperatures throughout the 14-day period. We can conclude that the stability of PACAP1-38 and PACAP1-27 was highly medium-dependent. We examined the more stable PACAP1-38 in a commercially available artificial tear solution as medium and found that the stability was lower than in any of the other media. Our findings were confirmed with RP-HPLC profiles of both the initial state and the least and most degraded PACAP1-27 and PACAP1-38 (Figs. 6-11). PACAP1-38 proved to be completely stable in water for injection at $+4{ }^{\circ} \mathrm{C}$ over a period of 2 weeks (Fig. 10).

\section{Discussion}

In the present study we showed the time course of degradation of PACAP1-27 and PACAP1-38 in different solutions at room temperature and at $+4{ }^{\circ} \mathrm{C}$. The results show that PACAP1-38 has significantly higher stability than PACAP1-27 at both RT and $+4{ }^{\circ} \mathrm{C}$ in each medium, with the longest stability in $0.9 \%$ saline solution and water for injection.

Naturally occurring or exogenously injected PACAP1-38 and 1-27 are degraded by several peptidases in the blood (Bourgault et al. 2009). Dipeptidyl peptidase IV (DPPIV) cleaves PACAP1-38 to the PAC1 receptor antagonist PACAP3-38 and 5-38 fragments, while PACAP1-27 is more resistant to DPPIV but is readily cleaved by neutral endopeptidase, similar to the structurally homologous VIP. Other

Table 1 Stability of PACAP1-27 in different media and conditions over a period of 2 weeks. The numbers in the cells indicate the percentage of the starting material that was not decomposed on the given day

\begin{tabular}{|c|c|c|c|c|c|c|c|c|}
\hline \multirow[t]{2}{*}{ PACAP1-27 } & \multicolumn{2}{|c|}{$0.9 \%$ Saline solution } & \multicolumn{2}{|c|}{$\begin{array}{l}\text { Benzalkonium chloride solution } \\
\text { for ophthalmic use (SOCB) }\end{array}$} & \multicolumn{2}{|c|}{$\begin{array}{l}\text { Thimerosal solution for } \\
\text { ophthalmic use }\end{array}$} & \multicolumn{2}{|c|}{ Water for injection } \\
\hline & RT & $+4{ }^{\circ} \mathrm{C}$ & $\mathrm{RT}$ & $+4{ }^{\circ} \mathrm{C}$ & RT & $+4{ }^{\circ} \mathrm{C}$ & $\mathrm{RT}$ & $+4{ }^{\circ} \mathrm{C}$ \\
\hline Day 3 & 76 & 96 & 72 & 91 & 49 & 93 & 80 & 98 \\
\hline Day 6 & 73 & 91 & 59 & 78 & 44 & 84 & 52 & 95 \\
\hline Day 8 & 54 & 89 & 31 & 77 & 30 & 82 & 38 & 92 \\
\hline Day 11 & 43 & 83 & 24 & 72 & 27 & 70 & 37 & 91 \\
\hline Day 14 & 39 & 79 & 7 & 65 & 22 & 62 & 25 & 90 \\
\hline
\end{tabular}

$R T$ room temperature 

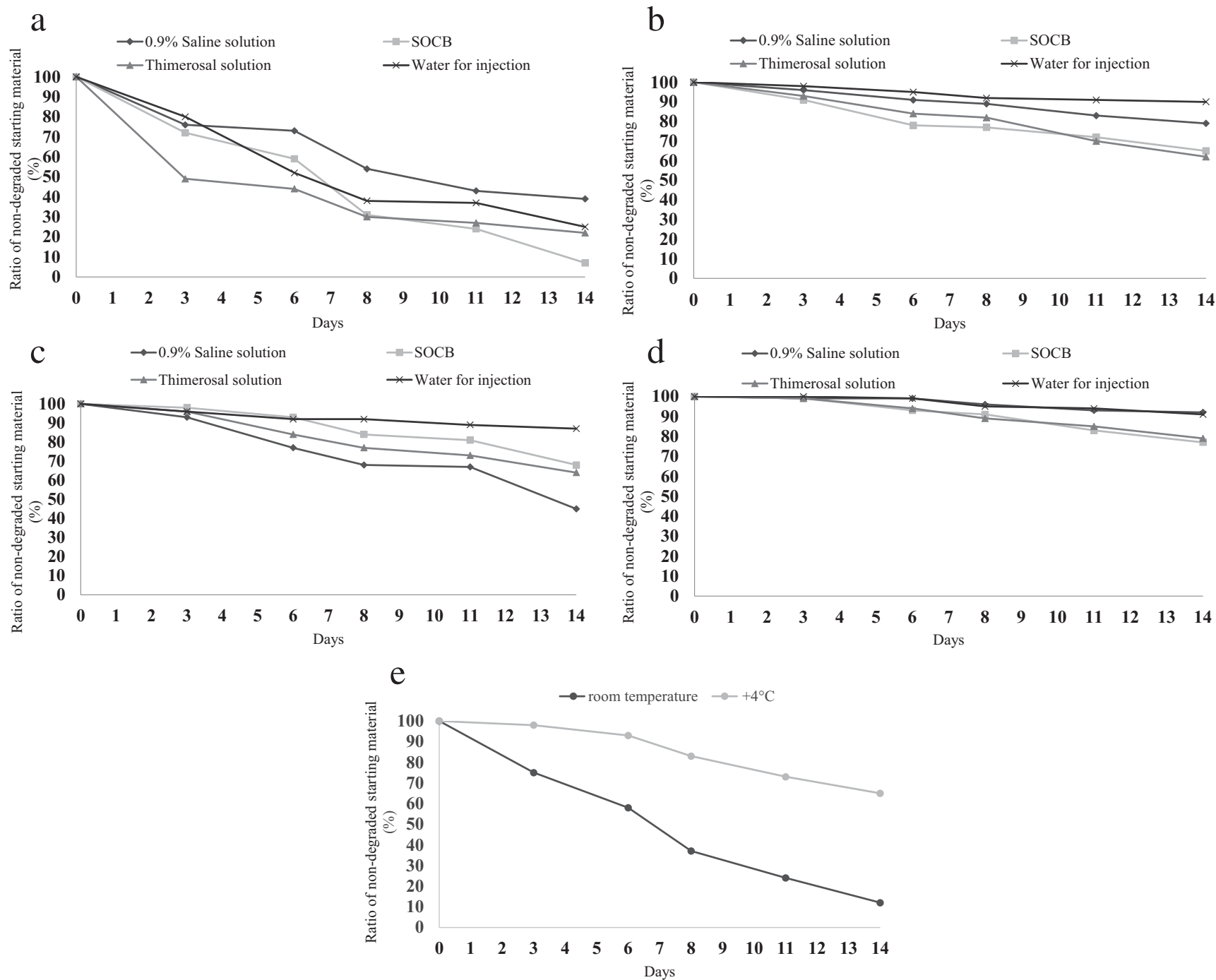

Fig. 1 Degradation of PACAP1-27 and PACAP1-38 at room temperature (RT) and at $+4{ }^{\circ} \mathrm{C}$ in four media $(0.9 \%$ saline solution, SOCB, thimerosal solution, water for injection) (a-d). We found that all four solutions demonstrated significantly higher stability at $+4{ }^{\circ} \mathrm{C}$ than at $\mathrm{RT}$, and the rate of degradation was higher in the SOCB and thimerosal solutions than in saline or water vehicles. PACAP1-38 was also more stable than PACAP1-27 in the four media. Degradation of PACAP1-38 in Systane ${ }^{\circledR}$ Ultra at RT and $+4{ }^{\circ} \mathrm{C}(\mathbf{e})$. Higher stability was found at $+4{ }^{\circ} \mathrm{C}$, similar to the other examined media

system and lead to neuroprotective effects. Several other routes of administration have been proven to provide protective effects of PACAP in the nervous system and peripheral organs, such as intracerebral, intrathecal, intracerebroventricular, intravitreal and systemic treatments, as well as intravenous, intraperitoneal and subcutaneous administration. Other options include emerging therapeutic approaches such as intranasal and eye drop treatments (Cabezas-Llobet et al. 2018; Meredith et al. 2015; Reglodi et al. 2018a). As far as protection in the eye is concerned, the intravitreal approach is the first choice for treatment in animal models of ocular diseases (Atlasz et al. 2016; Kiss et al. 2006; Reglodi et al. 2018a). This approach has led to the demonstration of the retinoprotective effects of PACAP in models of retinal hypoperfusion (Atlasz et al. 2007), traumatic optic nerve injury (Seki et al. 2008), 

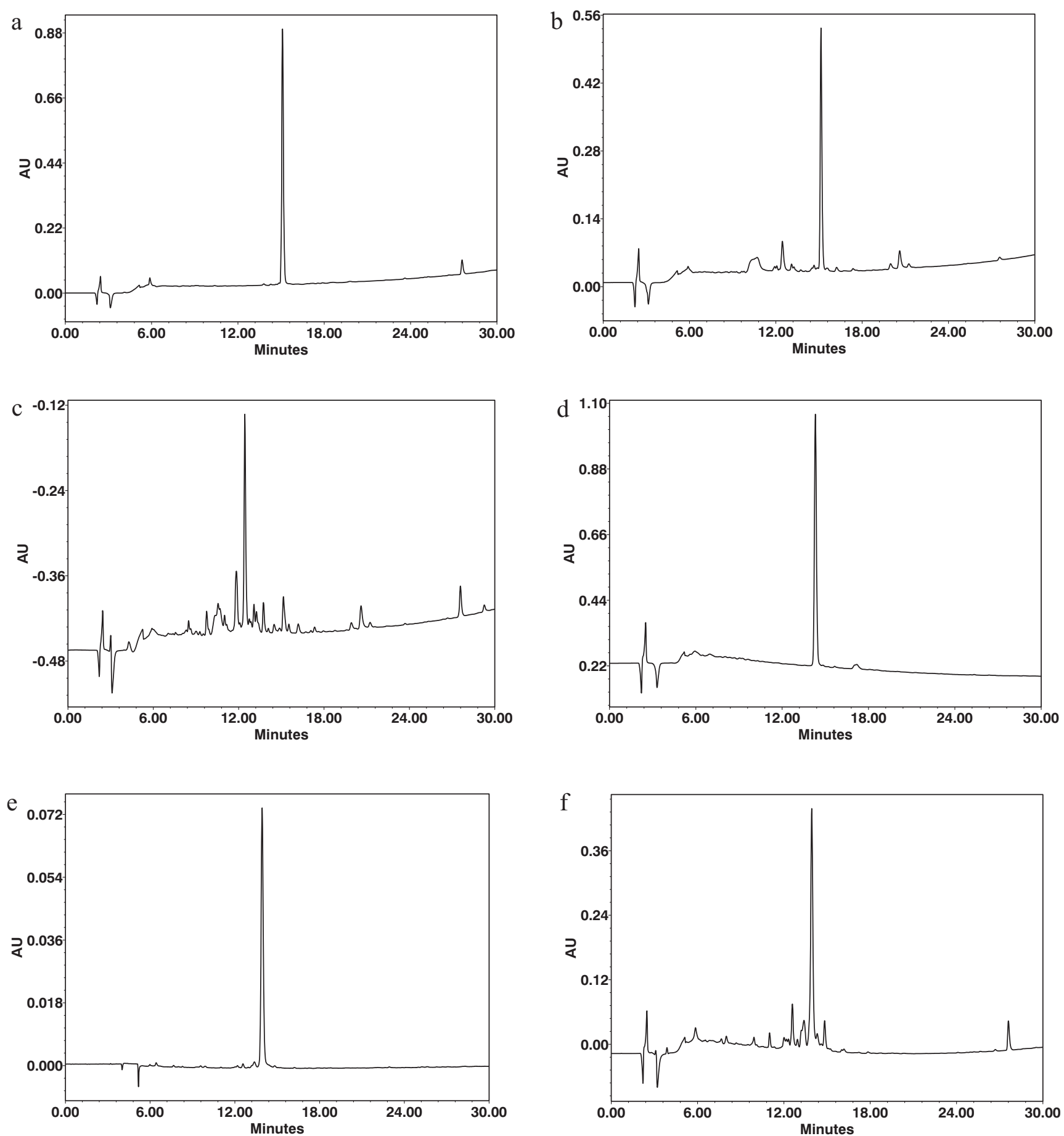

Fig. 2 PACAP1-27 initial state $t_{R}=15.14 \min (\mathbf{a})$. The most stable PACAP1-27 after day 14 medium: water for injection, temperature: $+4{ }^{\circ} \mathrm{C}(\mathrm{b})$. The most degraded PACAP1-27 after day 14 medium: SOCB, temperature: room temperature (c). PACAP1-38 initial state $\mathrm{t}_{\mathrm{R}}=13.94 \mathrm{~min}(\mathbf{d})$. The most stable PACAP1-38 after day 14 medium:

kainate- and glutamate-induced excitotoxicity (Atlasz et al. 2009; Seki et al. 2006), UV light-induced lesion (Atlasz et al. 2011), lipopolysaccharide-induced inflammation (Vaczy et al. 2018), oxygen-induced retinopathy of prematurity (Kvarik et al. 2016), diabetic retinopathy (D’Amico et al.

water for injection, temperature: $+4{ }^{\circ} \mathrm{C}(\mathbf{e})$. The most degraded PACAP138 after day 14 medium: SOCB, temperature: room temperature (f). Conditions: $0-100 \%$ B in $30 \mathrm{~min}, 220 \mathrm{~nm}, 1.2 \mathrm{~mL} / \mathrm{min}$, eluent A: $0.1 \%$ TFA $/ \mathrm{H}_{2} \mathrm{O}$, eluent B: $80 \% \mathrm{AcN} / 0.1 \% \mathrm{TFA} / \mathrm{H}_{2} \mathrm{O}$

2017; Szabadfi et al. 2016) and high intraocular pressureinduced retinopathy (Seki et al. 2011).

Although intravitreal treatments are commonly used in ophthalmological practice, it is an invasive method, with potential side effects and patient discomfort. PACAP, in the form of eye 
Table 2 Stability of PACAP1-38 in different media and conditions over a period of 2 weeks. The numbers in the cells indicate the percentage of the starting material that was not decomposed on the given day

\begin{tabular}{|c|c|c|c|c|c|c|c|c|}
\hline \multirow[t]{2}{*}{ PACAP1-38 } & \multicolumn{2}{|c|}{$0.9 \%$ Saline solution } & \multicolumn{2}{|c|}{$\begin{array}{l}\text { Benzalkonium chloride solution } \\
\text { for ophthalmic use (SOCB) }\end{array}$} & \multicolumn{2}{|c|}{$\begin{array}{l}\text { Thimerosal solution for } \\
\text { ophthalmic use }\end{array}$} & \multicolumn{2}{|c|}{ Water for injection } \\
\hline & RT & $+4{ }^{\circ} \mathrm{C}$ & RT & $+4{ }^{\circ} \mathrm{C}$ & $\mathrm{RT}$ & $+4^{\circ} \mathrm{C}$ & RT & $+4{ }^{\circ} \mathrm{C}$ \\
\hline Day 3 & 93 & 99 & 98 & 99 & 96 & 99 & 96 & 100 \\
\hline Day 6 & 77 & 99 & 93 & 93 & 84 & 94 & 92 & 99 \\
\hline Day 8 & 68 & 96 & 84 & 91 & 77 & 89 & 92 & 95 \\
\hline Day 11 & 67 & 93 & 81 & 83 & 73 & 85 & 89 & 94 \\
\hline Day 14 & 45 & 92 & 68 & 77 & 64 & 79 & 87 & 91 \\
\hline
\end{tabular}

$R T$ room temperature

drops, has been shown to lead to extension of neuronal processes from amputated nerve trunks in the cornea following laserassisted in situ keratomileusis and to accelerate recovery of corneal sensitivity after the surgery (Fukiage et al. 2007). Corneal application of PACAP1-27 eye drops or of a PACAP-derived peptide, with higher stability and PAC1specific potency than PACAP, also led to enhancement of corneal wound healing in mice (Ma et al. 2015). PACAP treatment in the form of eye drops is also able to increase tear secretion and cAMP and pPKA levels, in addition to the suppression of corneal keratinization and dose-dependent corneal wound healing in mice and rats (Farkas et al. 2010; Nakamachi et al. 2016). We recently showed that both PACAP1-27 and PACAP1-38 given in the form of eye drops could readily cross the ocular surfaces and could reach the retina in a concentration high enough to exert retinoprotective effects in a model of retinal ischemia (Werling et al. 2016, 2017). These results offer a potential novel therapeutic approach to treating retinal diseases. The use of PACAP in eye drops, therefore, would be beneficial not only in corneal diseases, but also in retinal pathologies. The emerging potential of PACAP in the form of eye drops led us to investigate the degradation process of PACAP127 and PACAP1-38 in the most commonly used solvents at two different temperatures, room temperature and $+4^{\circ} \mathrm{C}$, which are

Table 3 Stability of PACAP1-38 in a commercially available artificial tear solution (Systane ${ }^{\circledR}$ Ultra). Numbers in the cells indicate the percentage of the starting material that was not decomposed on the given day

\begin{tabular}{lll}
\hline PACAP1-38 & \multicolumn{2}{l}{ Artificial tears $\left(\right.$ Systane ${ }^{\circledR}$ Ultra) } \\
\cline { 2 - 3 } & RT & $+4{ }^{\circ} \mathrm{C}$ \\
\hline Day 3 & 75 & 98 \\
Day 6 & 58 & 93 \\
Day 8 & 37 & 83 \\
Day 11 & 24 & 73 \\
Day 14 & 12 & 65 \\
\hline
\end{tabular}

$R T$ room temperature important from both an experimental and clinical perspective. The present results provide a future reference for PACAP solutions to be used in the treatment of ocular disease.

Acknowledgements This work was supported by the following grants: NAP 2017-1.2.1-NKP-2017-00002, NKFIH129190, Bolyai Scholarship, GINOP-2.3.2-15-2016-00050 "PEPSYS", MTA-TKI 14016, EFOP3.6.2-16-2017-00008, EFOP 3.6.1-16.2016.00004, UNKP-19-3-IIIPTE-127, UNKP-19-3-1-PTE-137, UNKP-18-4-1-PTE-364, UNKP-164-IV, Centre for Neuroscience, PTE AOK Research Grant KA-2017-15, PTE AOK-TANDEM 2019 Grant, "The role of neuro-inflammation in neurodegeneration: from molecules to clinics"; Higher Education Institutional Excellence Program of the Ministry of Human Capacities in Hungary, within the framework of the FIKPII; TUDFO/47138-1/ 2019-ITM FIKP program.

Funding Information Open access funding provided by University of Pécs (PTE).

Open Access This article is licensed under a Creative Commons Attribution 4.0 International License, which permits use, sharing, adaptation, distribution and reproduction in any medium or format, as long as you give appropriate credit to the original author(s) and the source, provide a link to the Creative Commons licence, and indicate if changes were made. The images or other third party material in this article are included in the article's Creative Commons licence, unless indicated otherwise in a credit line to the material. If material is not included in the article's Creative Commons licence and your intended use is not permitted by statutory regulation or exceeds the permitted use, you will need to obtain permission directly from the copyright holder. To view a copy of this licence, visit http://creativecommons.org/licenses/by/4.0/.

\section{References}

Atlasz T, Babai N, Kiss P et al (2007) Pituitary adenylate cyclase activating polypeptide is protective in bilateral carotid occlusion-induced retinal lesion in rats. Gen Comp Endocrinol 153:108-114. https:// doi.org/10.1016/j.ygcen.2006.12.022

Atlasz T, Szabadfi K, Kiss P et al (2008) PACAP-mediated neuroprotection of neurochemically identified cell types in MSG-induced retinal regeneration. J Mol Neurosci 36:97-104. https://doi.org/10.1007/ s12031-008-9059-5 
Atlasz T, Szabadfi K, Kiss P et al (2011) Effects of PACAP in UV-A radiation-induced retinal degeneration models in rats. J Mol Neurosci 43:51-57. https://doi.org/10.1007/s12031-010-9392-3

Atlasz T, Szabadfi K, Reglodi D et al (2009) Effects of pituitary adenylate cyclase activating polypeptide and its fragments on retinal degeneration induced by neonatal monosodium glutamate treatment. Ann N Y Acad Sci 1163:348-352. https://doi.org/10.1111/j.1749-6632. 2008.03650.x

Atlasz T, Vaczy A, Werling D et al (2016) Neuroprotective effects of PACAP in the retina. In: Reglodi D, Tamas A (eds) Pituitary Adenylate Cyclase Activating Polypeptide - PACAP. Springer Nature, New York, pp 501-527

Atlasz T, Werling D, Song S et al (2019) Retinoprotective effects of TATbound vasoactive intestinal peptide and pituitary adenylate cyclase activating polypeptide. J Mol Neurosci 68:397-407. https://doi.org/ 10.1007/s12031-018-1229-5

Banks WA (2016) Transport of pituitary adenylate cyclase activating polypeptide across the blood-brain barrier: consequences for disease states and therapeutic effects. In: Reglodi D, Tamas A (eds) Pituitary Adenylate Cyclase Activating Polypeptide - PACAP. Springer Nature, New York, pp 423-432

Bourgault S, Vaudry D, Dejda A, Doan ND, Vaudry H, Fournier A (2009) Pituitary adenylate cyclase-activating polypeptide: focus on structure-activity relationships of a neuroprotective peptide. Curr Med Chem 16:4462-4480. https://doi.org/10.2174/ 092986709789712899

Cabezas-Llobet N, Vidal-Sancho L, Masana M, Fournier A, Alberch J, Vaudry D, Xifró X (2018) Pituitary adenylate cyclase-activating polypeptide (PACAP) enhances hippocampal synaptic plasticity and improves memory performance in Huntington's disease. Mol Neurobiol 55:8263-8277. https://doi.org/10.1007/s12035-0180972-5

Cheng HH, Ye H, Peng RP, Deng J, Ding Y (2018) Inhibition of retinal ganglion cell apoptosis: regulation of mitochondrial function by PACAP. Neural Regen Res 13:923-929. https://doi.org/10.4103/ 1673-5374.232489

Cline DL, Short LI, Forster MAM, Gray SL (2019) Adipose tissue expression of PACAP, VIP, and their receptors in response to cold stress. J Mol Neurosci 68:427-438. https://doi.org/10.1007/ s12031-018-1099-x

D'Amico AG, Maugeri G, Rasà DM et al (2017) Modulation of IL-1 $\beta$ and VEGF expression in rat diabetic retinopathy after PACAP administration. Peptides 97:64-69. https://doi.org/10.1016/j.peptides. 2017.09.014

Dorner GT, Wolzt M, Eichler HG, Schmetterer L (1998) Effect of pituitary adenylate cyclase activating polypeptide 1-27 on ocular, cerebral and skin blood flow in humans. Naunyn Schmiedeberg's Arch Pharmacol 358:657-662. https://doi.org/10.1007/PL00005308

Endo K, Nakamachi T, Seki T et al (2011) Neuroprotective effect of PACAP against NMDA-induced retinal damage in the mouse. J Mol Neurosci 43:22-29. https://doi.org/10.1007/s12031-010-9434-

Fabian E, Reglodi D, Horvath G et al (2019) Pituitary adenylate cyclase activating polypeptide acts against neovascularization in retinal pigment epithelial cells. Ann N Y Acad Sci. https://doi.org/10.1111/ nyas. 14189

Fabian E, Reglodi D, Mester L et al (2012) Effects of PACAP on intracellular signaling pathways in human retinal pigment epithelial cells exposed to oxidative stress. J Mol Neurosci 48:493-500. https://doi. org/10.1007/s12031-012-9812-7

Farkas J, Mester L, Kovacs K et al (2010) Effects of pituitary adenylate cyclase activating polypeptide (PACAP) in corneal epithelial regeneration and signal transduction in rats. Presented at the 5th International Peptide Symposium, December 4-9, 2010 Kyoto, Japan. Abstract
Fukiage C, Nakajima T, Takayama Y, Minagawa Y, Shearer TR, Azuma M (2007) PACAP induces neurite outgrowth in cultured trigeminal ganglion cells and recovery of corneal sensitivity after flap surgery in rabbits. Am J Ophthalmol 143:255-262. https://doi.org/10.1016/ j.ajo.2006.10.034

Fulop DB, Humli V, Szepesy J et al (2019) Hearing impairment and associated morphological changes in pituitary adenylate cyclase activating polypeptide (PACAP)-deficient mice. Sci Rep 9:14598. https://doi.org/10.1038/s41598-019-50775-z

Gabriel R, Postyeni E, Denes V (2019) Neuroprotective potential of pituitary adenylate cyclase activating polypeptide in retinal degenerations of metabolic origin. Front Neurosci 13:1031. https://doi.org/ 10.3389/fnins.2019.01031

Gourlet P, Vandermeers A, Robberecht P, Deschodt-Lanckman M (1997) Vasoactive intestinal peptide (VIP) and pituitary adenylate cyclaseactivating peptide (PACAP-27, but not PACAP-38) degradation by the neutral endopeptidase EC 3.4.24.11. Biochem Pharmacol 54: 509-515. https://doi.org/10.1016/s0006-2952(97)00207-4

Horvath G, Opper B, Reglodi D (2019) The neuropeptide pituitary adenylate cyclase-activating polypeptide (PACAP) is protective in inflammation and oxidative stress-induced damage in the kidney. Int $\mathrm{J}$ Mol Sci:20. https://doi.org/10.3390/ijms20194944

Jozsa G, Fulop BD, Kovacs L et al (2019) Lack of pituitary adenylate cyclase-activating polypeptide (PACAP) disturbs callus formation. J Mol Neurosci. https://doi.org/10.1007/s12031-019-01448-Z

Kiss P, Tamás A, Lubics A et al (2006) Effects of systemic PACAP treatment in monosodium glutamate-induced behavioral changes and retinal degeneration. Ann N Y Acad Sci 1070:365-370. https://doi.org/10.1196/annals.1317.046

Kvarik T, Mammel B, Reglodi D et al (2016) PACAP is protective in a rat model of retinopathy of prematurity. J Mol Neurosci 60:179-185. https://doi.org/10.1007/s12031-016-0797-5

Laszlo E, Juhasz T, Varga A et al (2019) Protective effect of PACAP on ischemia/reperfusion-induced kidney injury of male and female rats: gender differences. J Mol Neurosci 68:408-419. https://doi.org/10. 1007/s12031-018-1207-y

Liu Y, Lu T, Zhang C et al (2019) Pituitary adenylate cyclase-activating polypeptides prevent hepatocyte damage by promoting yesassociated protein in liver ischemia-reperfusion injury. Transplantation 103:1639-1648. https://doi.org/10.1097/TP. 0000000000002742

Ma Y, Zhao S, Wang X, Shen S, Ma M, Xu W, Hong A (2015) A new recombinant PACAP-derived peptide efficiently promotes corneal wound repairing and lacrimal secretion. Invest Ophthalmol Vis Sci 56:4336-4349. https://doi.org/10.1167/iovs. 15-17088

Maugeri G, D'Amico AG, Amenta A et al (2019c) Protective effect of PACAP against ultraviolet $B$ radiation-induced human corneal endothelial cell injury. Neuropeptides. 101978. https://doi.org/10. 1016/j.npep.2019.101978

Maugeri G, D'Amico AG, Bucolo C, D'Agata V (2019a) Protective effect of PACAP-38 on retinal pigmented epithelium in an in vitro and in vivo model of diabetic retinopathy through EGFR-dependent mechanism. Peptides 119:170108. https://doi.org/10.1016/j. peptides.2019.170108

Maugeri G, D'Amico AG, Castrogiovanni P et al (2019b) PACAP through EGFR transactivation preserves human corneal endothelial integrity. J Cell Biochem 120:10097-10105. https://doi.org/10. $1002 /$ jcb. 28293

Maugeri G, Longo A, D'Amico AG et al (2018) Trophic effect of PACAP on human corneal endothelium. Peptides 99:20-26. https://doi.org/ 10.1016/j.peptides.2017.11.003

Meredith ME, Salameh TS, Banks WA (2015) Intranasal delivery of proteins and peptides in the treatment of neurodegenerative diseases. AAPS J 17:780-787. https://doi.org/10.1208/s12248-015-9719-7

Miyata A, Jiang L, Dahl RD et al (1990) Isolation of a neuropeptide corresponding to the $\mathrm{N}$-terminal 27 residues of the pituitary 
adenylate cyclase activating polypeptide with 38 residues (PACAP38). Biochem Biophys Res Commun 170:643-648. https://doi.org/10.1016/0006-291X(90)92140-U

Nakamachi T, Ohtaki H, Seki T et al (2016) PACAP suppresses dry eye signs by stimulating tear secretion. Nat Commun. https://doi.org/10. 1038/ncomms 12034

Parsons RL, May V (2019) PACAP-induced PAC1 receptor internalization and recruitment of endosomal signaling regulate cardiac neuron excitability. J Mol Neurosci 68:340-347. https://doi.org/10.1007/ s12031-018-1127-x

Polanco MJ, Pennuto M (2018) Pituitary adenylyl cyclase activating polypeptide (PACAP) signaling and the cell cycle machinery in neurodegenerative diseases. Curr Pharm Des 24:3878-3891. https://doi.org/10.2174/1381612825666181127102311

Reglodi D, Atlasz T, Jungling A, Szabo E, Kovari P, Manavalan S, Tamas A (2018a) Alternative routes of administration of the neuroprotective pituitary adenylate cyclase activating polypeptide. Curr Pharm Des 24:3892-3904. https://doi.org/10.2174/ 1381612824666181112110934

Reglodi D, Atlasz T, Szabo E et al (2018d) PACAP deficiency as a model of aging. Geroscience 40:437-452. https://doi.org/10.1007/s11357018-0045-8

Reglodi D, Illes A, Opper B, Schafer E, Tamas A, Horvath G (2018c) Presence and effects of pituitary adenylate cyclase activating polypeptide under physiological and pathological conditions in the stomach. Front Endocrinol (Lausanne) 9:90. https://doi.org/10.3389/ fendo.2018.00090

Reglodi D, Renaud J, Tamas A, Tizabi Y, Socías SB, Del-Bel E, RaismanVozari R (2017) Novel tactics for neuroprotection in Parkinson's disease: role of antibiotics, polyphenols and neuropeptides. Prog Neurobiol 155:120-148. https://doi.org/10.1016/j.pneurobio.2015. 10.004

Reglodi D, Tamas A, Jungling A et al (2018b) Protective effects of pituitary adenylate cyclase activating polypeptide against neurotoxic agents. Neurotoxicology 66:185-194. https://doi.org/10.1016/j. neuro.2018.03.010

Reglodi D, Vaczy A, Rubio-Beltran E, MaassenVanDenBrink A (2018e) Protective effects of PACAP in ischemia. J Headache Pain 19:19. https://doi.org/10.1186/s10194-018-0845-3

Seki T, Itoh H, Nakamachi T, Endo K, Wada Y, Nakamura K, Shioda S (2011) Suppression of rat retinal ganglion cell death by PACAP following transient ischemia induced by high intraocular pressure. J Mol Neurosci 43:30-34. https://doi.org/10.1007/s12031-0109410-5

Seki T, Itoh H, Nakamachi T, Shioda S (2008) Suppression of ganglion cell death by PACAP following optic nerve transection in the rat. J Mol Neurosci 36:57-60. https://doi.org/10.1007/s12031-008-9091-

Seki T, Izumi S, Shioda S, Zhou CJ, Arimura A, Koide R (2000a) Gene expression for PACAP receptor mRNA in the rat retina by in situ hybridization and in situ RT-PCR. Ann N Y Acad Sci 921:366-369. https://doi.org/10.1111/j.1749-6632.2000.tb06995.x

Seki T, Nakatani M, Taki C et al (2006) Neuroprotective effect of PACAP against kainic acid-induced neurotoxicity in rat retina. Ann N Y Acad Sci 1070:531-534. https://doi.org/10.1196/annals.1317.074

Seki T, Shioda S, Izumi S, Arimura A, Koide R (2000b) Electron microscopic observation of pituitary adenylate cyclase activating polypeptide (PACAP)-containing neurons in the rat retina. Peptides 21:109113. https://doi.org/10.1016/S0196-9781(99)00180-1
Shioda S, Nakamachi T (2015) PACAP as a neuroprotective factor in ischemic neuronal injuries. Peptides 72:202-207. https://doi.org/ 10.1016/j.peptides.2015.08.006

Shioda S, Takenoya F, Hirabayashi T, Wada N, Seki T, Nonaka N, Nakamachi T (2019) Effects of PACAP on dry eye symptoms, and possible use for therapeutic application. J Mol Neurosci 68:420 426. https://doi.org/10.1007/s12031-018-1087-1

Szabadfi K, Atlasz T, Kiss P et al (2012) Protective effects of the neuropeptide PACAP in diabetic retinopathy. Cell Tissue Res 348:37-46. https://doi.org/10.1007/s00441-012-1349-0

Szabadfi K, Reglodi D, Szabo A et al (2016) Pituitary adenylate cyclase activating polypeptide, a potential therapeutic agent for diabetic retinopathy in rats: focus on the vertical information processing pathway. Neurotox Res 29:432-446. https://doi.org/10.1007/s12640015-9593-1

Szegeczki V, Bauer B, Jungling A et al (2019) Age-related alterations of articular cartilage in pituitary adenylate cyclase-activating polypeptide (PACAP) gene-deficient mice. Geroscience 41:775-793. https://doi.org/10.1007/s11357-019-00097-9

Vaczy A, Kovari P, Kovacs K et al (2018) Protective role of endogenous PACAP in inflammation-induced retinal degeneration. Curr Pharm Des 24:3534-3542. https://doi.org/10.2174/ 1381612824666180924141407

Vaczy A, Reglodi D, Somoskeoy T et al (2016) The protective role of PAC1-receptor agonist maxadilan in BCCAO-induced retinal degeneration. J Mol Neurosci 60:186-194. https://doi.org/10.1007/ s12031-016-0818-4

Van C, Condro MC, Lov K et al (2019) PACAP/PAC1 regulation of inflammation via catecholaminergic neurons in a model of multiple sclerosis. J Mol Neurosci 68:439-451. https://doi.org/10.1007/ s12031-018-1137-8

Vaudry D, Falluel-Morel A, Bourgault S et al (2009) Pituitary adenylate cyclase-activating polypeptide and its receptors: 20 years after the discovery. Pharmacol Rev 61:283-357. https://doi.org/10.1124/pr. 109.001370

Wang ZY, Alm P, Hakanson R (1995) Distribution and effects of pituitary adenylate cyclase-activating peptide in the rabbit eye. Neuroscience 69:297-308. https://doi.org/10.1016/0306-4522(95)00258-K

Werling D, Banks WA, Salameh TS et al (2017) Passage through the ocular barriers and beneficial effects in retinal ischemia of topical application of PACAP1-38 in rodents. Int J Mol Sci 18(3) pii: E675. https://doi.org/10.3390/ijms18030675

Werling D, Reglodi D, Banks WA et al (2016) Ocular delivery of PACAP1-27 protects the retina from ischemic damage in rodents. Invest Ophthalmol Vis Sci 57:6683-6691. https://doi.org/10.1167/ iovs. 16-20630

Yamaji K, Yoshitomi T, Usui S (2005) Action of biologically active peptides on monkey iris sphincter and dilator muscles. Exp Eye Res 80:815-820. https://doi.org/10.1016/j.exer.2004.12.020

Ye D, Shi Y, Xu Y, Huang J (2019a) PACAP attenuates optic nerve crushinduced retinal ganglion cell apoptosis via activation of the CREBBcl-2 pathway. J Mol Neurosci 68:475-484. https://doi.org/10. 1007/s12031-019-01309-9

Ye D, Yang Y, Lu X, Xu Y, Shi Y, Chen H, Huang J (2019b) Spatiotemporal expression changes of PACAP and its receptors in retinal ganglion cells after optic nerve crush. J Mol Neurosci 68: 465-474. https://doi.org/10.1007/s12031-018-1203-2

Publisher's Note Springer Nature remains neutral with regard to jurisdictional claims in published maps and institutional affiliations. 